\title{
The United Nations Committee on the Rights of the Child: Does its structure and working methods optimize efficacy and promote child participation?
}

\author{
Cindy Blackstock, PhD \\ Executive Director, First Nations Child and Family Caring Society of Canada, \\ Professor, School of Social Work, McGill University
}

International human rights law is born from a desire to interrupt a long history of state perpetrated human rights violations culminating in the Holocaust during the Second World War. Early human rights advocates such as Eleanor Roosevelt understood that the preservation of human freedom and dignity are essential to the wider aims of international peace and security promoted by the then, newly formed, United Nations. ${ }^{\text {i }}$ Tragedies like the Holocaust reinforced the belief that the international community required a set of human rights norms with enforcement measures to quell human rights abuses within and among states. It was in this spirit that the United Nations General Assembly adopted the Universal Declaration on Human Rights ${ }^{\mathrm{ii}}$ (UDHR) in 1948. ${ }^{\mathrm{iii}}$ Although declarations are not legally binding in international law, the UDHR gave birth to a series of binding human rights treaties, also known as Covenants and Conventions, including the United Nations Convention on the Rights of the Child ${ }^{\text {iv }}$ (hereinafter referred to as the UNCRC or Convention).

Canadian Supreme Court Justice Rosalee Abella draws a distinction between the way states apply rigorous sanctions to enforce international trade agreements versus the lackadaisical approach to human rights treaty enforcement suggesting that the United Nations (UN) and its human rights monitoring bodies share in the blame as they "play fast and loose with their legitimacy and integrity ${ }^{v}$." The Committee has no mechanism to 
independently monitor the implementation of its Concluding Observations between State Party reviews.

Conventions, like the United Nations Convention on the Rights of the Child, are theoretically binding, but, as Justice Abella points out, the international community has been lax in its enforcement. ${ }^{\mathrm{vi}}$ Although it is theoretically possible for a resolution to be brought before the United Nations Security Council to apply sanctions against a State Party for failing to comply with its obligations pursuant to the Convention, it has never been done. Even if such a resolution were to be successful, it would be subject to a possible veto by one or more of the five permanent members of the United Nations Security Council namely the United States, the United Kingdom, France, China and Russia. ${ }^{\text {vii }}$ In the absence of a serious movement by State Parties to implement enforcement measures akin to those in international trade agreements, the implementation of the Convention will largely be left to the discretion of ratifying states. In situations where international law falls short on enforcement, the efficacy of human rights treaty monitoring bodies in providing credible, independent and precise observations to enhance implementation domestically is even more important.

As the most ratified human rights treaty in the world, the United Nations Convention on the Rights of the Child offers a useful lens to explore the efficacy of United Nations Treaty body monitoring mechanisms particularly given its focus on an especially vulnerable population. ${ }^{\text {viii }}$ The United Nations Committee for the Rights of the Child (hereinafter referred to as the Committee) is charged with monitoring the implementation of the Convention by ratifying States Parties. The four pillars of the Convention are: non-discrimination, best interests of the child, survival and development and child participation. This paper discusses the constitution and working methods of the Committee before suggesting that its membership requirements and working methods are inadequate to optimize alignment with the four pillars of the Convention and ensure persons of high moral character and credential fill Committee ranks. Recommendations for reform are proposed.

\section{Appointment of Committee Members}


The aims of the UNCRC are set out in the preamble of the Convention and can broadly be characterized as recognizing that children are human rights bearers warranting due attention to their developmental needs and special role in society. ${ }^{\text {ix }}$ It follows that Committee members should embody the ideals of the Convention and ensure its working methods enable the children's best interests, participation, survival and development, and non-discrimination. This invites an exploration of the current mechanisms for the nomination and election of Committee members and monitoring performance postappointment.

Pursuant to Article 43 (3) of the Convention, States Parties can nominate one potential member from their citizenry for election at a meeting of ratifying States. The intent of the nomination and election process is to ensure that Committee members have the requisite knowledge, experience, and skills to monitor the implementation of the Convention. However, the Convention only provides general guidance on Committee member nominee qualifications and the election process offers few assurances that States Parties will elect the best-qualified nominees.

The criteria for nominees is set out in Article 43 (2) noting that "[T]he Committee shall consist of eighteen experts of high moral standing and recognized competence in the field covered by this Convention." Article 43 (2) also requires that nominees have "recognized competence in the field covered by this Convention." The United Nations High Commission on Human Rights which oversees the work of the Committee, however, interprets Article 43 (2) to mean "recognized competence in the field of human rights. ." This raises the question as to whether a person competent in human rights is necessarily equipped to understand and monitor children's rights. Justice Frankfurter of the United States Supreme Court cautions the transference of adult-oriented legal structures to children noting that "[c]hildren have a very special place in life which law should reflect. Legal theories and their phrasing in other cases readily lead to fallacious reasoning if uncritically transferred towards children. ${ }^{\text {xi, }}$ Even if one assumes 'human rights' can be interpreted to mean 'child rights,' existing member nomination and election procedures offer little assurance that persons nominated by states meet this standard. 
The only other language in the Convention regarding the qualifications of Committee nominees is that they must be of "high moral character." The problem is that there are no normative standards on what counts as "high moral character" meaning States have a wide degree of discretion interpreting this provision. In my view, the absence of more specific norms raises concerns about competence and child safety. For example, although basic employment background reviews and criminal record and child abuse registry checks are pre-requisites to serving as a volunteer or professional working with children in many developed countries, there is no such requirement that Committee members undergo such checks. Instead of relying on a vetting process by international child rights experts, the Convention assumes that rogue nominees will not survive the election process as other States Parties will not vote for persons who do not meet international standards of "high moral character." While that assumption has some basis, the political nature of the United Nations means that States may be persuaded to vote to gain favour on other matters regardless of the nominee's qualifications and moral character.

Another barrier to qualified child rights experts serving on the Committee relates to the position's remuneration. The United Nations pays Committee members a token amount of $\$ 1.00$ U.S.D. per annum meaning that Committee members must either be independently wealthy or avail themselves of another source of income (often sponsorship by their nominating State Party). The voluntary nature of the position means that many qualified persons are practically disqualified from service or serve at the financial pleasure of their sponsoring State Party or institution. Even when members receiving State Party financial support act with the highest level of integrity, legitimate questions can be raised about the appearance of conflict of interest.

The vague nature of nomination criteria, the wide discretion of States Parties to interpret and vet nominees pursuant to the criteria and financial support barriers risk the appointment of Committee members who are not well versed on children's rights generally or on child participation more specifically. This situation is further complicated by the fact that the Convention contains no specific mechanism for the removal of a Committee member against their will and the Committee itself has not exercised its discretion to develop such procedures pursuant to Article 43 (8). While some argue that 
independence can only be assured if tenure on the Committee is ensured, ${ }^{\text {xii }}$ the particular vulnerability of children requires that, at a bare minimum, there should be removal procedures for persons found criminally responsible for the maltreatment of children.

Despite the enumerated shortcomings in the Committee member nomination and election process, many members are eminently qualified and dedicated to excellence in children's rights. However, the competence and suitability of all Committee members cannot be taken for granted.

\section{The Monitoring Process}

In order to better assess the Committee's preparedness to monitor State Party implementation of the Convention, it is necessary to describe the monitoring procedure. The reporting requirements for States Parties are described in Article 45 of the Convention. The process requires ratifying States Parties to submit a report on the implementation of the UNCRC every five years to the Committee. Once the Committee has received the report, it is posted on the Committee website and expert bodies such as UNICEF, domestic NGO's and child rights experts and children themselves can submit responses to the State party report. These responses are often referred to as "alternative reports" or "shadow reports." Once the Committee has reviewed the State Party's report and the associated alternative reports, it invites individuals and organizations that submitted alternative reports to meet with the Committee in Geneva, Switzerland for what is called a pre-session meeting. At these meetings, experts and groups can briefly summarize their key points and recommend questions that the Committee should ask of

the State Party when it appears before the Committee. ${ }^{\text {xiii }}$ States Parties do not attend the pre-session events in order to provide a safe venue for non-governmental actors, including children themselves, to make submissions without fear of retaliation.

Until recently the mechanisms available for child participation were limited to those who could financially afford to go to Geneva or send a letter. The Committee has more recently widened its submission protocols to welcome video, Skype and social media participation by children in the pre-sessions. Once the Committee has considered all of the materials submitted at the pre-session event, it sends written questions to the State Party for response prior to the State Party appearing in person before the 
Committee. During the State Party report, the State delegation makes a brief opening remark before opening the floor to questions by the Committee. It is important to note that the State Party report is a conversation between the State and the Committee; presentations or questions by others are not part of the process. Approximately 2-3 weeks after the in-person meeting between the State Party and the Committee, the Committee releases its Concluding Observations. Concluding observations include statements by the Committee assessing the State's compliance with the Convention and recommendations to address areas requiring increased compliance. These Concluding Observations provide a baseline for subsequent State Party reviews as the Committee requires States to report on the implementation status of any recommendations made during previous reviews.

While the Committee's inclusion of non-State Party actors in alternative report submission and pre-session meeting participation is very positive, there are some organizational and practical constraints that hamper the ability of these groups to meaningfully participate. First and foremost, the Convention itself is a highly legal and formulaic document that baffles common understanding and while UNICEF has tried to make the Convention more accessible by publishing a child friendly version, ${ }^{\text {xiv }}$ its summary nature is insufficient to inform a thoughtful and impactful alternative report. Moreover, the working methods of the Committee are only available in non-child friendly text in the United Nations official languages, meaning that even if citizens understand the Convention they may not be able to figure out how they can participate in the monitoring process.

Another challenge to the participation of non-State Party actors relates to financial capacity. Although several articles of the Convention compel States to fulfill the obligations of the Convention to the extent their financial capacity makes possible, States are not obligated to financially support non-State Party actors to prepare an alternative report or participate in pre-session meetings that can be a barrier to participation. While it is possible to send an alternative report electronically, the Committee restricts presession submissions to in-person delegates/delegations or submissions via videoconferencing. This poses a significant participation barrier to the most disadvantaged groups who arguably are in the greatest need of the Convention's protections. It goes 
without saying that it is more often that poor children are the least likely to have access to video-conferencing or travel to Geneva. This leads to an overall critique of the Committee's integration of child participation, one of the cornerstone rights of the Convention, into its own reporting process.

While the Committee released working methods for the participation of children in the reporting process of the Committee on the Rights of the Child, ${ }^{\mathrm{xv}}$ very few of these guidelines apply to the operation of the Committee itself and some seem entirely out of kilter with child development. For example, consider the Committee's requirement that children be bound by the condition that all pre-session transactions be held in strict confidence. While there are circumstances where privacy protections must be afforded in the children's best interests such as a child's disclosure of maltreatment, the broad sweeping nature of this secrecy requirement goes too far. Keeping secrets is often associated with child harming behaviour, something the Convention stands strictly against. Even though the context of the Committee requiring the children to keep secret the pre-session transactions is not akin to abuse, it fails to recognize that many children are incapable of appreciating that distinction. It also completely ignores the fact that for many of these children, meeting with the United Nations Committee is the highlight of their lives and that not allowing them to share their experiences with their loved ones is unreasonable and arguably does not further the objectives of the Convention which are, among other things, to promote greater child participation and understanding of the Convention.

Another area for reform involves the pre-session hearing process. Currently, children attend at the pre-session meeting with adults and largely participate on many of the same terms as adults. ${ }^{\text {xi }}$ The meetings are held in a room that looks very much like a courtroom and pre-session procedures are highly formal and very time limited. Translation is restricted to the six official United Nations languages namely Arabic, English, French, Russian, Spanish and Chinese. ${ }^{\text {xvii }}$ Typically, the Committee restricts delegates to a 2-5 minute opening statement followed by succinct answers to Committee questions. My personal experience of the process is that many adults are intimidated by the structure and children find it to be even more of a challenge. 
While the Committee recognizes the limitations of the pre-session meetings by offering a private meeting between children and the Committee members, these meetings also require reform. For instance, the meetings are conducted exclusively in English so children who speak other languages must make arrangements for translation by a trusted adult. This places a significant burden on children that is not faced by adults participating in the pre-session where translation in UN languages is available. Even if the child is able to secure a trusted English speaking person to translate, concerns about the quality and integrity of the translation inevitably arise. The Committee could exercise its discretion pursuant to Article 43 (8) to make arrangements for whisper translation in the child's first language but often cites financial constraints as a reason for not making such a service available. It is true that the Committee operates on a shoe-string budget meaning that hard choices have to be made on spending priorities. However, children are the raison d'etre of the Convention and thus should be afforded top priority in the allocation of translation resources.

The faulty confidentiality requirements critiqued above encumber children's meetings as well. Some children and children's groups try to mitigate the shortcomings in the Committee's child participation procedures by including older youth (aged 18-24) in the delegation to comfort and mentor the children. However, the Committee recently adopted working methods restricting participation in the children's meetings to children aged 18 and under which means that incorporating young people in these meetings is no

longer possible. ${ }^{\text {xviii }}$ While some may argue that the age restriction makes sense given that the Convention itself defines a child as someone under the age of 18 , this bright line distinction fails to account for variances in development, children with disabilities and differences in cultural constructs of childhood. Article 45 (8) of the Convention makes clear that matters such as eligible meeting attendees falls entirely within the discretion of the Committee thus they could adopt a more flexible approach.

\section{Strengthening Committee Membership and Working Methods}

While any changes to the text of the Convention would require the approval of the General Assembly and ratifying States, the Committee can take positive measures to ensure top-flight candidates fill its ranks and to better situate itself to fulfill its monitoring 
role. All UN monitoring bodies have the ability to create interpretive documents called General Comments that clarify provisions of the respective Convention for States Parties or guide States Parties on the implementation of the entire Convention for special populations. General Comments are drafted by the Committee in consultation with experts and are not subject to State Party review or approval. The Committee on the Rights of the Child has issued a wide array of general comments on specific articles such as the right to play and on the application of the Convention to particularly vulnerable groups of children such as children with disabilities and Indigenous children. ${ }^{\text {xix }}$ It is open to the Committee to develop a General Comment to guide States on the nomination and election of Committee members pursuant to Article 43 of the Convention. Although not binding, a General Comment would at least set a consistent standard on the requisite knowledge, skills and experiences required of Committee nominees and promote consistency and transparency in the nomination and election processes.

The Committee could also exercise its discretion pursuant to Article 43(8) to create procedures for the discipline and involuntary removal of members who pose a risk to children or act in ways contrary to the Convention. Frankly it is astounding that no such measures currently exist particularly as the Committee should be an exemplar of how accountable and effective child rights organizations function.

Moreover, the Committee itself should be subject to rules of procedure and normative standards of conduct that are publicly known and invite the public, including children, to file complaints and have those complaints processed in keeping with the principles of due process and best interests of the child. No such mechanisms currently exist and, while it is vital that Committee members be protected from politically motivated complaints, such concerns can be mitigated by due process mechanisms.

\section{Conclusion}

While the Committee is constrained by scant financial resources for translation and burdened by its limited resources to manage the high volume of periodic reviews, there are some basic practical reforms that could enhance its efficacy and better promote child participation. The Committee should employ available mechanisms to optimize the quality of Committee members and create due process mechanisms for the removal of 
members who pose a risk to children or conduct themselves in a manner inconsistent with the Convention. From a child participation perspective, the Committee could implement these practical reforms: 1) allowing for the submission of alternative reports and participation in pre-session reviews via social media; 2) ensuring Committee members welcome children in a manner appropriate to their culture; 3 ) revising the confidentiality requirement for the pre-session to better reflect child development and avoid reinforcing negative secret-keeping behavior; 4) reviewing its operating procedures to look for opportunities to reduce the formality and rigidity to encourage children's participation; and 5) prioritizing the translation budget to support the participation of children in the monitoring process.

In conclusion, this critique and associated recommended reforms to the UN Committee membership and working methods are offered to raise State adhesion to the Convention to the same level of vigor that trade agreements are negotiated, respected and enforced. Children are worthy of our highest and most diligent efforts.

\section{Notes}

\footnotetext{
${ }^{\mathrm{i}}$ Eleanor Roosevelt, On the Adoption of the Universal Declaration on Human Rights, (Address to the General Assembly of The United Nations, 9 December 1948 in Paris, France), Retrieved from: http://www.americanrhetoric.com/speeches/eleanorrooseveltdeclarationhumanrights.htm ${ }^{\text {ii } U n i v e r s a l ~ D e c l a r a t i o n ~ o n ~ H u m a n ~ R i g h t s, ~ G . ~ A . ~ R e s . ~ 217 A ~(I I I), ~ U . N . ~ D o c . ~ A / 810 ~ a t ~} 71$ (1948). http://www.canadianlawyermag.com/legalfeeds/98/sccs-abella-says-international-justice-isfloundering.html Last visited November 13, 2015

${ }^{\mathrm{vi}}$ Supra note 2 at 1 .

vii Stephen Lendman, “Understanding The Un Security Council Veto Power." Retrieved from http://www.globalresearch.ca/understanding-the-un-security-council-veto-power/5477846 Last visited November 21, 2015.

viii UNICEF, “A World Of Difference: 25 Crc Achievements." Retrieved from http://www.unicef.org/crc/index_73549.html Last visited November 22, 2015

${ }^{\mathrm{ix}}$ Supra note 4 at 1.

${ }^{x}$ High Commission on Human Rights, Committee On The Rights Of The Child. Retrieved from http://www.ohchr.org/EN/HRBodies/CRC/Pages/Membership.aspx

${ }^{\mathrm{xi}}$ May v. Anderson, 345 U.S. 528, 536 (1953).

xii See Brandies Institute for International Judges, “Topics in Ethical Practice 2007.” Retrieved from

https://www.brandeis.edu/ethics/pdfs/internationaljustice/ethics/Topics\%20in\%20Ethical\%20Pra ctice2007.pdf
} 
xiii United Nations Committee on the Rights of the Child, "Working Methods." Retrieved from www.ohchr.org/Documents/HRBodies/CRC/CRC-C-66-2.doc Last visited November 23, 2015 ${ }^{\text {xiv }}$ UNICEF, "United Nations Convention On The Rights Of The Child In Child Friendly

Language." Retrieved from http://www.unicef.org/rightsite/files/uncrcchilldfriendlylanguage.pdf Last visited November 23, 2015

${ }^{\mathrm{xv}}$ United Nations Committee on the Rights of the Child. "Working Methods For The Participation Of Children In The Reporting Process Of The Committee On The Rights Of The Child" (2014).

${ }^{\text {xvi }}$ Supra note 5 at 6.

xvii United Nations, "Official Languages." Retrieved from http://www.un.org/en/sections/aboutun/official-languages/index.html Last visited November 23, 2015

xviii Supra note 6 at 6

${ }^{x i x}$ Office of the High Commission on Human Rights, List Of General Comments. Retrieved from http://tbinternet.ohchr.org/ layouts/treatybodyexternal/TBSearch.aspx?Lang=en\&TreatyID=5\&D ocTypeID $=11 \% 20$ Last visited November 23, 2015 